\title{
New Education Policy 2020 of India: A Theoretical Analysis
}

\author{
Dr. Hemlata Verma* and Adarsh Kumar** \\ *Assistant Professor, Dept. of Arts, Aditya College, Gwalior, Madhya Pradesh, India, Email: hemlatavermadhakre@gmail.com \\ **Assistant Professor, Dept. of Tourism \& Mgmt., Aditya College, Gwalior, Madhya Pradesh, India, Email: adarshlive9@gmail.com \\ *Correspondence: Adarsh Kumar; Email: adarshlive9@gmail.com
}

ABSTRACT: Education has a key and decisive role in this scenario of contingencies. The National Education Policy 2020 has therefore been transformed into the framework of this reform, which could help to build a new education system in the country, in addition to strengthening those economic and social indicators. That still needs to be improved. NEP 2020 provides for quality higher education through multidisciplinary universities and autonomous colleges. We have critically examined the policy in this paper and proposed changes to ensure a seamless continuum with its predecessor in addition to its predecessor, boosting its importance. The current paper describes the analysis of the requirements for NEP 2020 provisions and management practices at the university level. Recommendations are made for the design and implementation of NEPs at national and HEIs (Higher Education levels).

Keywords: National Education Policy, Teacher training, Indian Education, HEIs

\section{ARTICLE INFORMATION}

Author(s): Dr. Hemlata Verma and Adarsh Kumar

Received: 12 Apr, 2021; Accepted: 07 May, 2021; Published: 30 Aug, 2021; e-ISSN: 2347-4696;

Paper Id: IJBMR-2021-090801;

Citation: doi.org/10.37391/IJBMR.090308

Webpage-link:

https://ijbmr.forexjournal.co.in/archive/volume-9/ijbmr-090308.html

\section{INTRODUCTION}

Change is the eternal and unwavering rule of the universe. Here, it varies from moment to moment. No society is untouched by the process of change. Social change is the nature of society. Indian society is also no exception to this. It is known from the historical study of Indian society that many social, economic, political, and other changes have also taken place from the primitive era to the present era. There are mainly two types of change. One is the changes which are made by nature and the other types of changes are done by human beings themselves. Natural changes are not within our control. But through human change, one tries to innovate by bringing changes in life and society. Presently, if there is to be some change in terms of development in a society, then the education policy should be changed first. The picture of education in any country shows that the place of education is the priority of the government there and how much it deals with it.

After India fell behind in the list of better quality universities around the world in recent years, it was expected that the government and the entire system would take some concrete steps to improve the matter so that some improvement could be made in this situation. . Keeping in view the development objective of the entire country, the Indian government decided to change India's education policy after 34 years. To formulate a new education policy, the Central Government in 2017, Dr. K.K. Kasturirangan constituted a committee under the chairmanship of the Kasturirangan committee drafted the National Education Policy 2019. In India in July 2020, the
Central Government approved the National Education Policy 2020. In connection with this approval, Prime Minister Shri Narendra Modi tweeted and the Minister of Human Resource Development "Shri Ramesh Pokhriyal Nishak" made the public aware by the press conference. It was also clarified that the Ministry of Human Resource Development has been renamed as "Ministry of Education". Earlier in 1985, theMinistry of Education' was renamed as Ministry of Human Resource Development. In 2020, the name of the Ministry of Human Resource Development was again changed to the Ministry of Education after the introduction of a new education policy.

The first education policy was introduced in 1968 by the government of former Prime Minister Mrs. Indira Gandhi. The second education policy was formulated by the Rajiv Gandhi government in 1986, with some amendments by the Narasimha Rao government in 1992. The National Education Policy 2020 is the third education policy of independent India. Thus, a 34-year-old education policy is currently underway, which is becoming ineffective with the changing scenario. This is the reason that in the year 2019, the Ministry of Human Resource Development had drafted the new education policy and sought advice from the public.

Why the need for change in pre-education policy?

- To cater to the needs of a knowledge-based economy in the changing global scenario changes were needed in the current education system.

- New education to enhance the quality of education, promote innovation and research.

- In education policy to ensure global access to Indian educational system.

\section{WHAT IS IN NEW EDUCATION POLICY IN INDIA?}


Under the new education policy of 2020, the educational system has been fixed by 2030 . The curriculum will be divided on the basis of the educational system of $5+3+3+4$ in place of the currently running $10+2$ model. The target of investment of Central and State Government has also been set for the new Education Policy 2020 in which Central and State Governments will invest in education sector equal to 6 percent GDP of the country for cooperation in the education sector.

"We have tried to create a policy that will change the educational landscape in our understanding so that we can prepare the youth to face the current and future challenges. It has been a journey in which every member has taken a personal and collectively, we have tried to cover different dimensions of the broader educational landscape of our country. This policy is all based on the guiding objectives like access, capacity, quality, affordability, and accountability. From pre-primary to higher education, we have taken this field Seen in an uninterrupted continuity as well as encompassing other areas connected to the broader landscape"(K. Kasturiranjan, committee chairman)

\section{New Education Policy 2020 Phase}

The phases of the new education policy are divided into four phases. In the new policy, it has been completely abolished. The old education policy was organized on a $10+2$ formula, but the new education policy is based on the $5+3+3+4$ formula. The new pattern includes 3 years of schooling and 12 years of schooling. It has been made mandatory for government and non-government institutions to follow the new policy.

\section{Four steps of new education policy}

* Foundation Stage- Foundation Stage of New Education Policy for 3 to 8 years children are included. The Foundation Stage has been fixed for 5 years. In which 3 years of pre-school education will be done in Anganwadi and class 1, 2 school education under which the language skills and skill level of the students will be evaluated and focused in its development.

* Preparatory Stage - The time of this stage is kept for 3 years. This stage includes children from 8 to 11 years. In which he will have children up to class 5 . In this stage of the new education policy, special attention will be focused on strengthening the numerical skills of the students. At the same time, all children will also be given knowledge of the regional language. Along with this, children will be taught science, art, mathematics, etc. through experiments.

* Middle Stage - The period of this stage has been fixed for 3 years. In This stage Children from 6th grade to 8th grade have been included in which subject-based curriculum will be taught and coding will also be started from the children of 6th grade. At the same time, all the children will be given opportunities for vocational testing as well as vocational internship, whose aim is to make the children eligible for employment only during school education.

* Secondary Stage- The period of this stage is 4 years. 9th grade in this stage Students from 12th standard is included. In this, intensive study of the subjects will be done. Within this stage, the educational curriculum of 8th to 12th standard courses has also been started and the alternative educational course has been started. Students can choose their subjects according to their choice, not within a specified stream. Under the new education policy, students have been given the freedom to choose subjects. Students can study the subjects of science as well as the subject of Arts or Kormas simultaneously. Due to the earlier $10+2$ system, there was no pre-schooling in government schools. General from class 1 to 10 there was education and class 6 was a moist subject and there was freedom to choose subjects from class 6 . Education used to start in the first 6 years, but now it will start in 3 years.

- Board on students of 10 th and 12th, keeping in mind the goal of development before the students the format of board examinations will also be changed to reduce the burden of examinations. Improvements such as a semester or multiple choice questions will be included. The examination will be conducted 2 times a year. There will be objective and subjective tests once a year. The main emphasis in the board examination will be on the test of knowledge so that the tendency of rote among students can be eliminated. From this point of view, this thinking of the government is welcome.

- Assessment as a standard prescribing body for the assessment of the progress of students a new national assessment center will be established.

- $\quad$ "Artificial intelligence" based software will be used to evaluate the progress of the students and help the students to take decisions related to their future.

\section{Provisions related to higher education}

Gross enrollment ratio in higher educational institutions under National Education Policy 2020 it has been targeted to increase from 26.3 percent (the year 2018) to 50 percent also 3.5 crores new seat will be added in higher educational institutions.

The gross enrollment ratio is the number of total eligible population at an education level who has taken admission in educational institutions. For example, the total number of students in the age group eligible for admission to higher education is 100 but if the admission is taken by 60 , then this ratio will be 60 percent.

For all types of higher education except medical and legal education, a Higher Education Commission of India will be set up which will replace the UGC. A multidisciplinary education and research university equivalent to IITs and IIMs will be made. These institutes will be world-class. For admission in these, there will be a general entrance test, which will be conducted by the National Testing Agency. It will be an 
elective for all students, there will be no compulsory subject under this, the subjects of Arts and Humanities will also be taught in technical institutions. There will be no division like Arts, Science, and Commerce. Students can choose any subject of their choice. All the institutes of the country including IITs will adopt a holistic approach.

\section{Four bodies of Higher Education of Commission (HECI)}

- National Higher Education Regulatory Council (NHERC): It will act as a regulator for the higher education sector including teacher education.

- General Education Council (GEC): This will create the framework of expected learning outcomes for higher education programs, that is, their standardization work.

- National Accreditation Council (NAC): These institutions are accredited, Will function primarily based on basic criteria; public self-disclosure, good governance , and results.

- Higher Education Grants Council (HGFC): This body financing work for colleges and universities.

Currently, higher education bodies are regulated through bodies like University Grants Commission (UGC), All India Council for Technical Education (AICTE) and National Council for Teacher Education (NCTE).

Multiple entries and exit in the undergraduate curriculum in the National Education Policy 2020. The system has been adopted under this, in a three or four year undergraduate program, students will be able to leave the course at different levels and they will be awarded degrees or certificates accordingly. Like, Certificate after one year, Advanced Diploma after two years, and Bachelor's degree after three years after four years, Graduate Certificate with research. Students doing four years degree will be able to do Ph.D. with MA in one year. MPhil program has been abolished in the new education policy. The Academic Bank of Credit will be formed through this policy. In this, the digit or credit received by the students will be preserved digitally.

\section{Provisions related to online and digital education}

National Educational Technological Farm will be formed to promote digital education. It will carry out the work of coordination for digital infrastructure, materials, and capacity building. With this, study and assessment technology along with teaching training is an important part will form.

- To ensure the preparation of alternative means of quality education, the Ministry of Education will become a dedicated entity for digital infrastructure, digital content, and capacity building to cater to the e-education needs of both school and higher education.

- E-content will be made available for study in regional languages.

\section{Related to Advanced Education}

Target to achieve 100 percent youth and adult literacy by 2030 has been done.

\section{Protection of linguistic diversity}

In the new education policy, many options have been kept regarding languages. Class 5 and class 8 Priority has been suggested to study mother tongue or regional language as a study. Students will be able to take foreign language from secondary level i.e. 9 th grade.

- It will be mandatory to have at least two Indian languages in the tri language formula. In this, preference will be given to the choice of state, region, and student. For example, students studying Marathi and English languages in Mumbai will have to study a third language. No student will be affected by the choice of language, in the educational curriculum; there is an option to read Sanskrit and other traditional and ancient languages.

\section{Physical education}

Under the new education policy 2020, along with the education of students, skills will also be developed. In which all students from the minimum class will be given training in subjects like Horticulture, Yoga, Music, Dance, Sports, and Sculpture, etc. So baby Proficient in physical activities as well as other types of skills.

Recommendations related to the educational system

- Teachers' promotion will be arranged based on performance from time to time through the new education policy.

- The National Council for Teacher Education will develop a professional standard for teachers by the year 2022 .

- National level educational for teacher's education on the advice of NCERT Course content of the course will be prepared.

- Four-year B.Ed. degree for teaching in the new education policy by 2030 will be made mandatory.

Provision for differently-abled children

Changes in the educational curriculum for PWD through a new education policy have been done. For these, regular from basic stage to higher education will be enabled to participate fully in the education process.

Funding education

Emphasis is to invest up to 6 percent of GDP in the education sector. Present it is 4.43 percent of GDP.

Financial aid to students

- Efforts will be made to encourage the qualification of students belonging to SC, ST, OBC, and other specific categories.

- To support and progress the progress of students receiving student's stipends National scholarship portal will be expanded to track.

\section{Other announcements}

- In place of UGC, AICTE, NCTE in higher education, there will now be a single regulator that will direct institutions. 
- In 15 years, the process of affiliation with universities will be eliminated by giving autonomy to colleges. They will be made fully autonomous. They will be made autonomous colleges that award degrees or will be attached to a university.

- To give international shape to education, the top global ranking university will be allowed to open its branch in India, so that the students of India will not have to go abroad to get admission to the world's best colleges and universities.

- The National Research Foundation will be set up as an apex body to conduct research and to promote strong research culture and research potential in higher education.

- In the new education policy, emphasis will be laid on the establishment of education centers for the gender inclusion fund and deprived areas.

- The student's report card will be evaluated based on a 360-degree assessment, keeping in mind the mental abilities of his behavior, which will be evaluated by the student's classmate and teacher.

\section{CHALLENGES RELATED TO EDUCATION POLICY}

Cooperation - Education of states is a concurrent subject. This is why most states have their school boards. Therefore, the State Governments have to come forward for the actual implementation of this decision. Also, the idea of bringing a National Higher Education Regulatory Campus as the top controlling organization can be opposed by the states.

Expensive Education - The new education policy paves the way for admission to foreign universities. Various academics believe that admission to foreign universities is likely to be expensive for Indian educational system. As a result, it can be challenging for lower class students to pursue higher education.

Sanskritisation of education - South Indian states charge that the government is trying to Sanskritise education with the trilanguage formula. Many problems can arise in front of states even if the medium of education for children is in mother tongue or regional language. For example, people from different states live in a union territory like Delhi. In such a school there will be children who know different mother tongues. In which medium all these children will be educated, Whether or not English medium schools are in agreement with the vernacular concept. In primary school, in which medium the children will be able to get an education if the state changes.

Feeding-related inadequate investigation - Fees still exist in some states Regulation exists but these regulatory processes are unable to curb profiteering as unlimited donations.

Financing - Ensuring funding will depend on how strong the will power to spend the proposed 6 percent of GDP as public expenditure on education.
Lack of human resources - Currently skilled teachers in elementary education lacks. In such a situation, the implementation of the system made for elementary education under the National Education Policy 2020.

\section{SUGGESTIONS FOR NEW EDUCATION 2020 POLICY OF INDIA}

- The initial 5 years are included in early childhood care education. It will be implemented through Anganwadi. First, Anganwadi should be converted into Kids Zone so that the child can get an education in sports. Also, one of the two Anganwadi workers should be replaced by an ASHA worker and physiotherapy so that both education and health will work together. It is said that $85 \%$ of brain development takes place in this period. Therefore, to prepare a strong and capable generation in this, skilled training will have to be made available to the children in this period.

- Will receive education from class 3 to class 5 in the primary stage. Children between 8 and 11 years of age come. In this class, the child has to reduce the burden of books. In this phase, children should get an education through moral stories so that the round development of the child is possible. Bagless education should be imparted at this stage.

- In the secondary stage, the child develops knowledge about his environment. The government not only distributes bicycles, mid-day meals to children, as well as the facility of de-warding like Navodaya. Because of the economic problem in rural areas of India, they are unable to get an education by engaging in agricultural work and leave their education in between.

- Also, 50\% evaluation textbook and 50\% evaluation should be based on local arts promotion, culture and small cottage industries only then the concept of employment education will come true.

- In the presence of parents in addition to the provision of custom education in the higher secondary stage abstain from sexual education also.

- Internships in various areas of the country to the child through vocational training and entrepreneurship should be given so that children are aware of the geographical environment.

- Implementing all the declarations requires the strong political will of basic infrastructure.

- To improve education, universities must be made autonomous.

- 200 top ranked universities should be given full academic, administrative financial autonomy to diversify the updated curriculum to promote global innovation.

- Less money is spent on research in India. Research spent 0.7 percent of GDP in 2017-18. The United States spent 2.8 percent in China and 2.1 percent in Israel. To promote research in the new policy, the National Research Foundation needs to be set up on fast track messages. 
- Top Universities of India should produce more than 50,000 PhDs every year so that innovation and specialty talent can be improved.

- To increase the Gross Enrolment Ratio, the Central and State Governments should equally provide special packages to institutions.

- The new policy is emphasizing on the environment, sports, culture, research and development. There is a lack of basic infrastructure required to meet all these needs. For this, the government should arrange to give a large amount to the universities in the form of a loan for 20-30 years.

\section{CONCLUSION}

The new National Education Policy, 2020, which has been approved by the central government to change the Indian education system to meet the needs of 21 st century India, if it is implemented successfully, this new system will make India one of the world's leading countries. Equivalent Under the new education policy, 2020, children from 3 years to 18 years have been placed under the Right to Education Act, 2009. The aim of this new education policy, which came after 34 years, is to provide higher education to all students, which aims to universalize pre-primary education (age range of 3-6 years) by 2025 .

\section{REFERENCES}

[1] Amar Ujala 31 July 2020; now studying till 5th, an examination for admission in mother tongue till graduation.

[2] Dainik Jagran 30 July 2020; Let us know why a new national education policy was needed to change the education system of the country. https://www.education.gov.in/sites/upload_files/mhrd/files/Draft _NEP_2019_EN_Revised.pdf

[3] Draft National Education Policy 2019. Committee for Draft National Education Policy, Ministry of Human Resource Development, Government of India. https://www.education.gov.in/sites/upload_files/mhrd/files/Draft _NEP_2019_EN_Revised.pdf

[4] Govt. of India (1968). National Policy on Education,1968 https://www.education.gov.in/sites/upload_files/mhrd/files/docu ment-reports/NPE-1968.pdf

[5] Govt. of India (1986). National Policy on Education, 1986

[6] https://www.education.gov.in/sites/upload_files/mhrd/files/docu ment-reports/NPE86-mod92.pdf

[7] Govt. of India (2020).National Education Policy 2020. https://www.education.gov.in/sites/upload_files/mhrd/files/NEP _Final_English_0.pdf

[8] Government of India. (2020). National Education Policy 2020. Ministry of Human Resource Development. https://www.education.gov.in/sites/upload_files/mhrd/ files/NEP_Final_English_0.pdf

[9] Hindustan live 30 July 2020; New education policy, school education board exam, major changes in graduation degree, learn special things,

[10] Hindustan Times 2020.08.08;'NEP will play role in reducing gap between research and education in India'-PM Modi.
[11] India Today. (5 Sep 2020). How can schools implement the National Education Policy 2020 effectively? India Today. https://www.indiatoday.in/educationtoday/ featurephilia/story/how-can-schools-implement-nationaleducationpolicy- 2020-1718932-2020-09-05.

[12] Kumar, K., Prakash, A., Singh, K. (2020). How National Education Policy 2020 can be a lodestar to transform future generation in India. Journal of Public Affairs an international Journal, e2500, 1-5. https://doi.org/10.1002/pa.2500

[13] M. M. Goel (2020): A View on Higher Education in New Education Policy 2020.

[14] Punjab Kesari 29 July 2020, Chairman JP Nadda; said on the new education policy. New education policy takes into account the needs of new India Supporting the new education policy.

[15] Singh Saroj 30 July 2020 New Education Policy 2020 Only RSS agenda or talk of common people BBC Hindi Access Date 31 July 2020 .

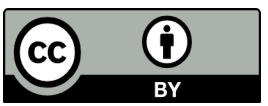

(C) 2021 by the Dr. Hemlata Verma and Adarsh kumar. Submitted for possible open access publication under the terms and conditions of the Creative Commons Attribution (CC BY) license (http://creativecommons.org/licenses/by/4.0/). 